Jpn. J. Pharm. Health Care Sci.

ノート 28(6) 564-570 (2002)

\title{
日本人におけるアロプリノール適正投与量の検討
}

\author{
岡田 博*, 老田 章, 上野和行, 高田充隆, 柴川雅彦 \\ 国立循環器病センター薬剤部†
}

\section{Evaluation of the Optimal Dosage of Alopurinol in Japanese Patients}

\author{
Hiroshi Okada*, Akira Oita, Kazuyuki Ueno, Mitsutaka Takada and Masahiko Shibakawa \\ Department of Pharmacy, National Cardiovascular Center $\dagger$
}

$\left[\begin{array}{l}\text { Received February 27, } 2002 \\ \text { Accepted August 5, } 2002\end{array}\right]$

\begin{abstract}
Allopurinol is often used for the treatment of patients suffering from gout and hyperuricemia. However, adverse effects due to the accumulation of oxipurinol, the main active metabolite of allopurinol, have been reported in patients with renal insufficiency. Therefore, in order to prevent such adverse effects, some guidelines for the optimal dosage of allopurinol have been advocated. To evaluate these guidelines, the serum oxipurinol concentration in 101 patients with hyperuricemia treated with allopurinol was measured by HPLC. The serum oxipurinol concentration/dosage increased $(\mathrm{p}<0.01)$ as the creatinine clearance level decreased. In addition, to evaluate the optimum dosage based on the renal function, $\mathrm{Ccr}$ was classified into three groups $(\mathrm{Ccr} \leqq 30 \mathrm{~mL} /$ $\min , 30 \mathrm{~mL} / \mathrm{min}<\mathrm{Ccr} \leqq 50 \mathrm{~mL} / \mathrm{min}, \mathrm{Ccr}<50 \mathrm{~mL} / \mathrm{min}$ ).

A positive correlation was observed between the dosage of allopurinol and the serum oxipurinol concentration in each group $(\mathrm{Ccr} \leqq 30 \mathrm{~mL} / \mathrm{min}, \mathrm{Ccr}<50 \mathrm{~mL} / \mathrm{min}: \mathrm{p}<0.0130 \mathrm{~mL} / \mathrm{min}<\mathrm{Ccr}: \leqq 50 \mathrm{~mL} / \mathrm{min}: \mathrm{p}<0.05)$.

Regarding the serum oxipurinol concentration/dosage in each group, it increased as the creatinine clearance level decreased $(\mathrm{p}<0.05)$.

Based on our findings, the optimal dosages of allopurinol in each group in Japanese are considered to be as follows :

1) $\mathrm{Ccr} \leqq 30 \mathrm{~mL} / \mathrm{min}: 50 \mathrm{mg} /$ day

2) $30 \mathrm{~mL} / \mathrm{min}<\mathrm{Ccr} \leqq 50 \mathrm{~mL} / \mathrm{min}: 100 \mathrm{mg} /$ day

3 ) $\mathrm{Ccr}<50 \mathrm{~mL} / \mathrm{min}: 200 \mathrm{mg} /$ day
\end{abstract}

Keywords - allopurinol, oxypurinol, renal insufficiency, pharmacokinetics

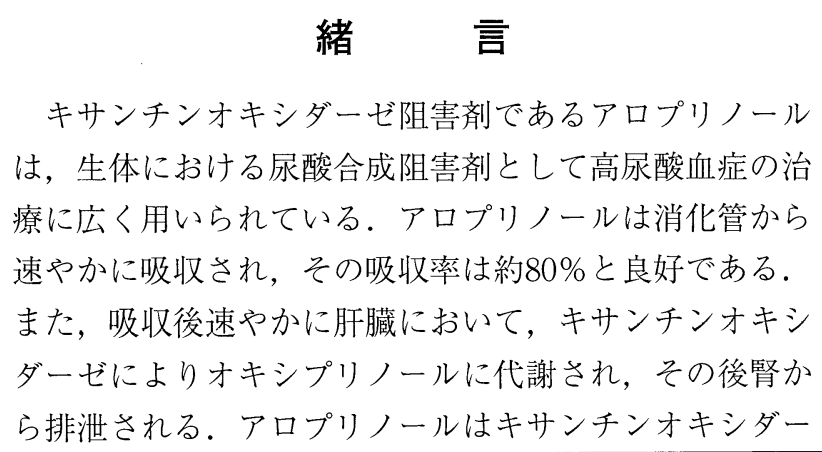

ゼを阻害するとともに，自らもキサンチンオキシダーゼ により代謝されオキシプリノールとなる．アロプリノー ルの半減期 $\left(\mathrm{t}_{1 / 2}\right)$ は $1 \sim 2$ 時間であるのに対し,オキ シプリノールは14〜26時間と非常に長い ${ }^{1-3)}$. また,ア ロプリノールは投与後約 2 時間で最高血中濃度に達し 6 時間後にはほとんど血中から消失するが，その後代謝物 であるオキシプリノールは，6時間後も血中濃度が上昇 する1). したがって，アロプリノール投与後の尿酸降下 作用はアロプリノールとその代謝物であるオキシプリ

$\dagger$ 大阪府吹田市藤白台 5-7-1；5-7-1, Fujishiro-dai, Suita-shi, Osaka, 565-8565 Japan 
ノールの両者によるものと考えられる。しかし，オキシ プリノールの排泄は主に腎から行われるため, 腎機能低 下患者では体内からの排泄が遅延する4).このため，才 キシプリノールの血中濃度上昇に伴う副作用の発現に注 意する必要があることから, 腎機能に基づく投与指針 が, Hande $^{4)}$ (Table 1) や細谷 ${ }^{5)}($ Table 2) によって提唱 されている.

われわれは，アロプリノール服用患者を対象に血清ア ロプリノールおよびオキシプリノールの血中濃度を測定 し，提唱されているこれらの投与指針について比較検討 を行ったので報告する。

\section{方法}

\section{1. 試料および試薬}

試薬の調整に用いた水は注射用蒸留水(大塚製薬 (株)），アセトニトリルは高速液体クロマトグラフィー (HPLC) 用 (和光純薬工業(株)), アロプリノール, オ キシプリノールは和光純薬工業(株), 標準物質 7-メチル キサンチンは SIGMA 社製，その他はHPLC 用または試 薬特級品を用いた.

Table 1. Maintenance Dose of Allopurinol for Adults Based on Individual Creatinine Clearance Measurements.

\begin{tabular}{cc}
\hline $\begin{array}{c}\text { Creatinine } \\
\text { Clearance } \\
(\mathrm{mL} / \mathrm{min})\end{array}$ & Maintenance Dose of Allopurinol \\
\hline 0 & $100 \mathrm{mg}$ every three days \\
10 & $100 \mathrm{mg}$ every two days \\
20 & $100 \mathrm{mg}$ daily \\
40 & $150 \mathrm{mg}$ daily \\
60 & $200 \mathrm{mg}$ daily \\
80 & $250 \mathrm{mg}$ daily \\
100 & $300 \mathrm{mg}$ daily \\
120 & $350 \mathrm{mg}$ daily \\
140 & $400 \mathrm{mg}$ daily \\
\hline
\end{tabular}

Table 2. 腎機能に応じたアロプリノール投与量の 目安

\begin{tabular}{cc}
\hline $\begin{array}{c}\text { クリアチニン・クリアランス } \\
(\mathrm{mL} / \mathrm{min})\end{array}$ & アロプリノール投与量 \\
\hline $\mathrm{Ccr}>50$ & $100 \sim 300 \mathrm{mg} /$ 日 \\
$30<\mathrm{Ccr} \leqq 50$ & $100 \mathrm{mg} /$ 日 \\
$\mathrm{Ccr} \leqq 30$ & $50 \mathrm{mg} /$ 日 \\
血液透析施行例 & 透析終了時に100mg以下 \\
腹膜透析施行例 & $50 \mathrm{mg} /$ 日 \\
\hline (東京慈恵会医科大学内科学講座第 2 における治療指針)
\end{tabular}

\section{2. 対象および期間}

平成10年 4 月から平成11年10月までの間に国立循環器 病センター $(\mathrm{NCVC})$ 腎・高血圧病棟あるいは心藏内科 病棟に入院し，アロプリノールを少なくとも 7 日以上投 与された患者101例（男性89例，女性12例）を対象とし た.クレアチニンクリアランス $(\mathrm{Ccr}: \mathrm{mL} / \mathrm{min})$ は Cockcroft-Gault 法を用いて血清クレアチニン值 (Scr)により 求めた。

$$
\begin{array}{ll}
\text { 男性 } & \mathrm{Ccr}=\{(140-\text { 年齢 }) \times \text { 体重 }\} /(72 \times \mathrm{Scr}) \\
\text { 女性 } & 0.85 \times \text { 男性の值 }
\end{array}
$$

\section{3. 採血方法}

採血はすべて前腕静脈より行った。採血時刻はすべて 朝 6：00の服用前（トラフ值）とし, 最終服用時間から 10〜24時間経過したものを対象とした.

採血の際には患者に対して本研究の目的・意義および 研究方法について十分説明を行った上承諾を得た.

\section{4. 血清中アロプリノール濃度およびオキシプリノール 濃度の測定方法}

血液試料は遠心分離（3000 rpm，10分間）にかけ，そ の上清 (血清) を測定に用いた。血清アロプリノールお よびオキシプリノール濃度は, 宮崎らの測定方法6)に従 いHPLC 法で測定した。装置は島津製作所 LC-6 A を 使用し，カラムは島津製作所 ODS-II (4.6mmI.D. ×25 $\mathrm{cm})$, 移動相は $4 \mathrm{mM}$ リン酸緩衝液 $(\mathrm{pH} 6.0)$ とアセト ニトリルの混液 $(98.5: 1.5)$ を用い, 流速 $1.2 \mathrm{~mL} / \mathrm{min}$, 検出波長 $254 \mathrm{~nm}$ の室温にて行った。本測定法の測定限 界はそれぞれ $25 \mathrm{ng} / \mathrm{mL}$ で, 変動係数 CV は $10 \%$ 以下で あった。

\section{5. 抽出法}

血清試料あるいはスパイク試料 $0.5 \mathrm{~mL}$ (アロプリノー ル $1 \mu \mathrm{g} / \mathrm{mL}$, オキシプリノール $40 \mu \mathrm{g} / \mathrm{mL}$ に調整）を 別々の試験管にとり，それぞれに標準物質 7-メチルキ サンチン水溶液 $(50 \mu \mathrm{g} / \mathrm{mL}), 400 \mu \mathrm{L}, 1.2 \mathrm{~N}$ 塩酸 $15 \mu \mathrm{L}$ を添加しジエチルエーテル $5 \mathrm{~mL}$ を加え混和後ジエチル エーテル相を分離し蒸発乾固した. 残査を移動相 $400 \mu \mathrm{L}$ に溶解し，その一部を HPLCに注入した。

\section{6. データの解析}

対象患者の年齢および体重は平均土標準偏差, 血清才 キシプリノール濃度/投与量とクレアチニンクリアラン スのデータは平均士標準誤差で示した．有意差検討には 解析ソフト Statcelを用いて, 回帰分析, 分散分析 Scheff's F 法による多重比較検定を用い, $\mathrm{p}<0.01$ また 
$\mathrm{Ccr} \leqq 30 \mathrm{~mL} / \mathrm{min}, \mathrm{B}$ 群 : $30 \mathrm{~mL} / \mathrm{min}<\mathrm{Ccr} \leqq 50 \mathrm{~mL} / \mathrm{min}, \mathrm{C}$

は $\mathrm{p}<0.05$ 有意差ありとした.

トラフにおけるオキシプリノールクリアランス (Coxi： $\mathrm{mL} / \mathrm{min}$ ) は次の方法で近似值を算定した.

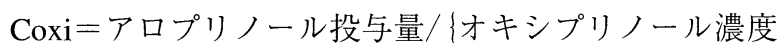
$\times$ 投与間隔

\section{結果}

対象患者の平均年齢（土標準偏差）は66.0土11.2歳 (男性66.0土11.3歳, 女性66.2 211.2 歳), 平均体重は

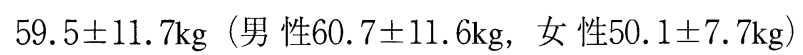
であった.アロプリノールの 1 日平均投与量は $137.5 \pm$ $61.5 \mathrm{mg} 1$ 日平均投与回数は $1.39 \pm 0.6$ 回であった.

対象患者の腎機能別内訳を, Table 3 に示した.

血清アロプリロール濃度は全検体において測定限界以 下であった。

体重あたりの投与量と血清オキシプリノール濃度との 関係を Fig. 1 に示した. 投与量の増加に伴い, 血清オ キシプリノール濃度は上昇する傾向が認められた。（ $\mathrm{y}=$ $\left.2.762 \mathrm{x}+8.460, \mathrm{R}^{2}=0.111, \mathrm{p}<0.01\right)$ ．腎機能別（A 群 :

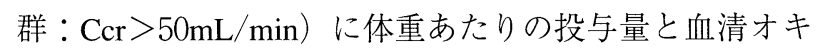
シプリノール濃度との関係を Fig. 2 に示した. 各群と も投与量の増加に伴い, 血清オキシプリノール濃度が上 昇する傾向が認められたが，腎機能が低い群ほどアロプ リノールの体重あたりの投与量に対する血清オキシプリ ノール濃度の変化が大きかった. クレアチニンクリアラ ンスと血清オキシプリノール濃度/投与量との関係を Fig. 3 に示した. クレアチニンクリアランスと血清オキ シプリノール濃度/投与量には負の相関が見られた（ $\mathrm{y}=$ $\left.23.789 \mathrm{x}^{-0.4171}, \mathrm{R}^{2}=0.389, \mathrm{p}<0.01\right)$. また, クレアチ ニンクリアランスが小さい患者において血清オキシプリ ノール濃度にばらつきが大きい傾向が認められた。ささら に, 腎機能別の各群における血清オキシプリノール濃度/ 投与量の比較を Fig. 4 に示した. クリアチニンクリア ランスが低いほど投与量あたりの血清オキシプリノール 濃度は高かった。アロプリノール服用が 1 日 1 回の患者 を対象とし，算出したオキシプリノールクリアランスと クリアチニンクリアランスの関係を Fig. 5 に示した.

Table 3. Characteristics of Patients.

\begin{tabular}{|c|c|c|c|c|c|c|c|c|c|}
\hline \multirow[t]{2}{*}{ Ccr } & \multicolumn{3}{|c|}{ Males } & \multicolumn{3}{|c|}{ Females } & \multicolumn{3}{|c|}{ Total } \\
\hline & $\mathrm{N}$ & $\begin{array}{l}\text { Age } \\
(\mathrm{y})\end{array}$ & $\begin{array}{c}\text { Body weight } \\
(\mathrm{kg})\end{array}$ & $\bar{N}$ & $\begin{array}{c}\text { Age } \\
(y)\end{array}$ & $\begin{array}{c}\text { Body weight } \\
(\mathrm{kg})\end{array}$ & $\mathrm{N}$ & $\begin{array}{l}\text { Age } \\
\text { (y) }\end{array}$ & $\begin{array}{c}\text { Body weight } \\
(\mathrm{kg})\end{array}$ \\
\hline $\mathrm{Ccr} \leqq 30 \mathrm{~mL} / \mathrm{min}$ & 40 & $68.8 \pm 10.8$ & $57.1 \pm 8.7$ & 10 & $65.7 \pm 12.0$ & $50.8 \pm 7.8$ & 50 & $68.2 \pm 11.0$ & $55.8 \pm 8.4$ \\
\hline $30 \mathrm{~mL} / \mathrm{min}<\mathrm{Ccr} \leqq 50 \mathrm{~mL} / \mathrm{min}$ & 16 & $69.0 \pm 6.9$ & $60.7 \pm 9.3$ & 1 & 74 & 40.9 & 17 & $69.3 \pm 6.8$ & $59.6 \pm 10.3$ \\
\hline $50 \mathrm{~mL} / \mathrm{min}<\mathrm{Ccr}$ & 33 & $61.1 \pm 12.2$ & $65.2 \pm 14.2$ & 1 & 69 & 51.3 & 34 & $61.1 \pm 12.0$ & $64.7 \pm 14.2$ \\
\hline
\end{tabular}

Ccr:Creatinine Clearance $(\mathrm{mL} / \mathrm{min})$

Values:mean \pm standard deviation

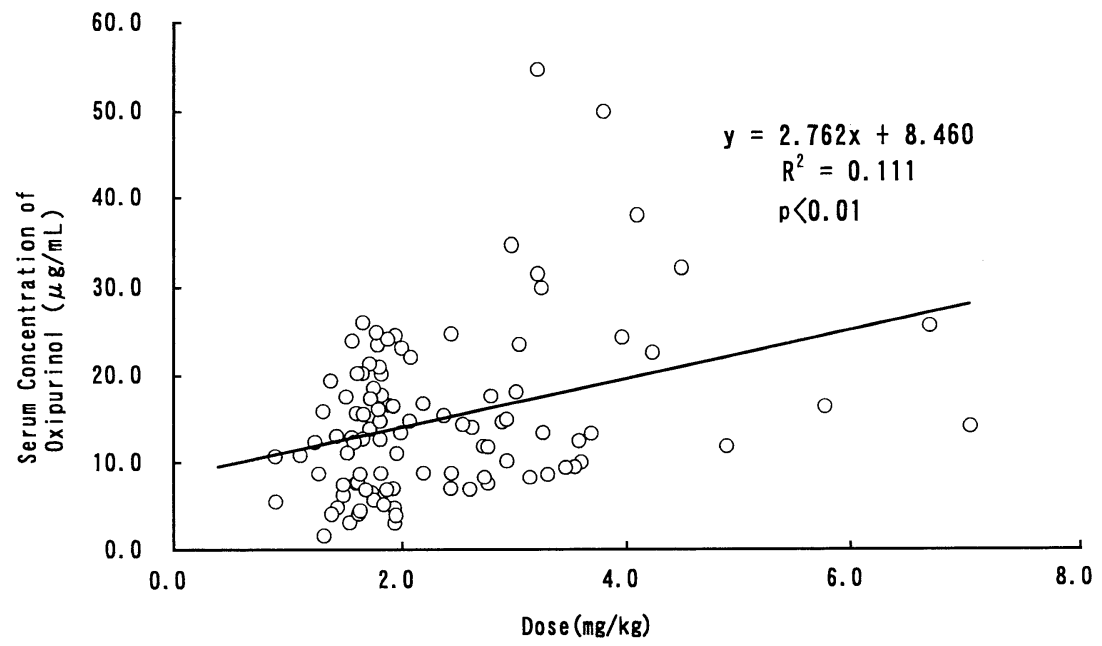

Fig. 1. Correlation between Serum Concentration of Oxipurinol $(\mu \mathrm{g} / \mathrm{mL})$ and Dose $(\mathrm{mg} / \mathrm{kg})$. 

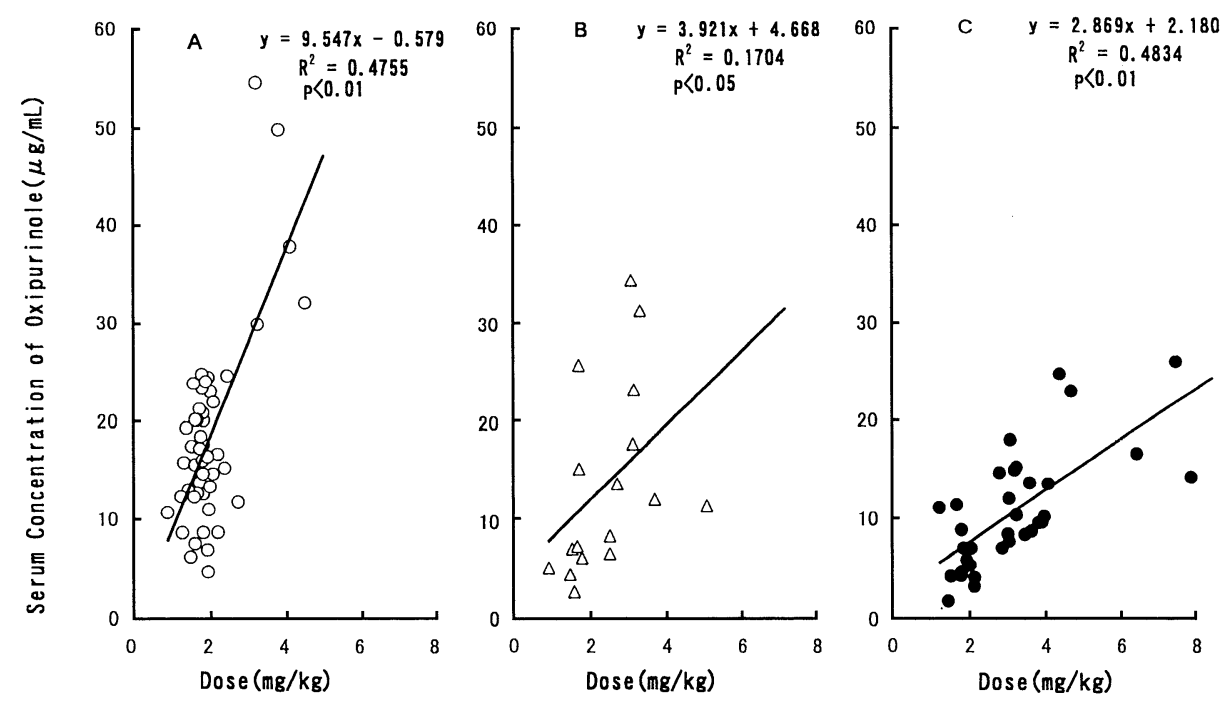

Fig. 2. Correlation between Serum Concentration of Oxipurinol $(\mu \mathrm{g} / \mathrm{mL})$ and Dose $(\mathrm{mg} / \mathrm{kg})$.
$\mathrm{A}: \bigcirc \mathrm{Ccr} \leqq 30 \mathrm{~mL} / \mathrm{min}$
$\mathrm{B}: \triangle 30 \mathrm{~mL} / \mathrm{min}<\mathrm{Ccr} \leqq 50 \mathrm{~mL} / \mathrm{min}$
$\mathrm{C}: \bigcirc \mathrm{Ccr}>50 \mathrm{~mL} / \mathrm{min}$

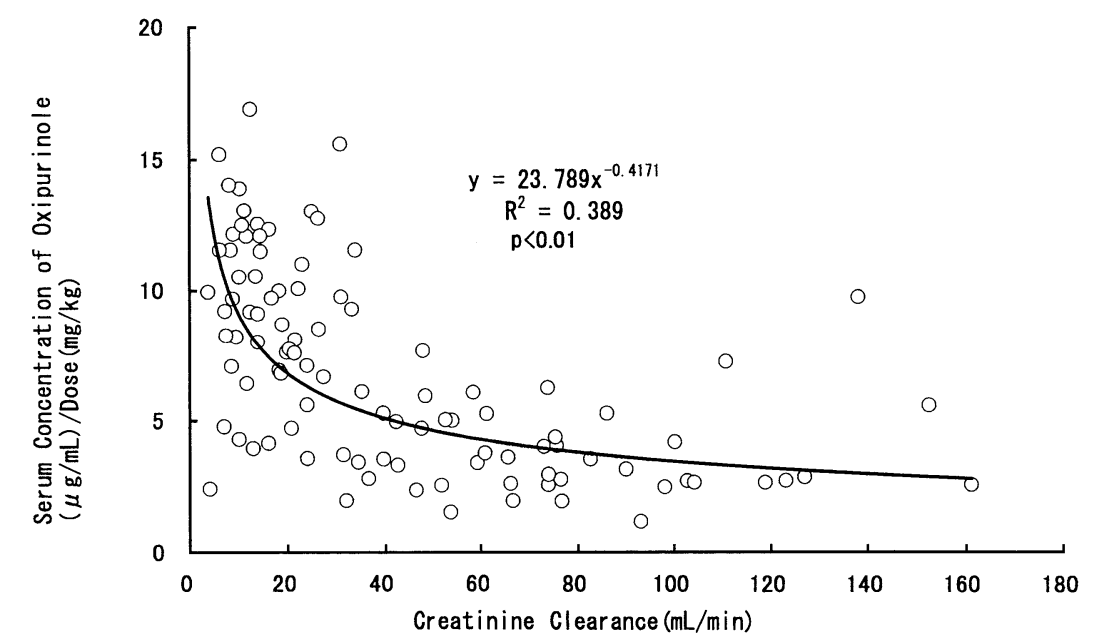

Fig. 3. Correlation between Creatinine Clearance (mL/ $\min )$ and Serum Concentration of Oxipurinol $(\mu \mathrm{g} / \mathrm{mL}) /$ Dose $(\mathrm{mg} / \mathrm{kg})$.

クリアチニンクリアランスが低下するほどオキシプリ ノールクリアランスは低下することが示唆された。（ $\mathrm{y}=$ $\left.0.113 \mathrm{x}+4.044, \mathrm{R}^{2}=0.3022, \mathrm{p}<0.01\right)$. 血清オキシプ リノール濃度と血清中の尿酸值をFig. 6 に示した。血 清オキシプリノール濃度と尿酸值に相関は認められな かった。

\section{考察}

すべての検体においてアロプリノールは検出されな
かった。この理由として，アロプリノール最終服用後少 なくとも10時間以上経過した時点での採血であり，アロ プリノールの $\mathrm{t}_{1 / 2}$ が $1 \sim 2$ 時間であり，ほとんど代謝さ れ測定限界以下になっていたためと考えられる。

腎機能障害によるクリアチニンクリアランスの低下に 伴い，血清オキシプリノール濃度が上昇することがすで に報告されているが4)，Fig. 3 に示したように同様の結 果が得られた。

また, Fig. 1 から血清オキシプリノール濃度は用量依 


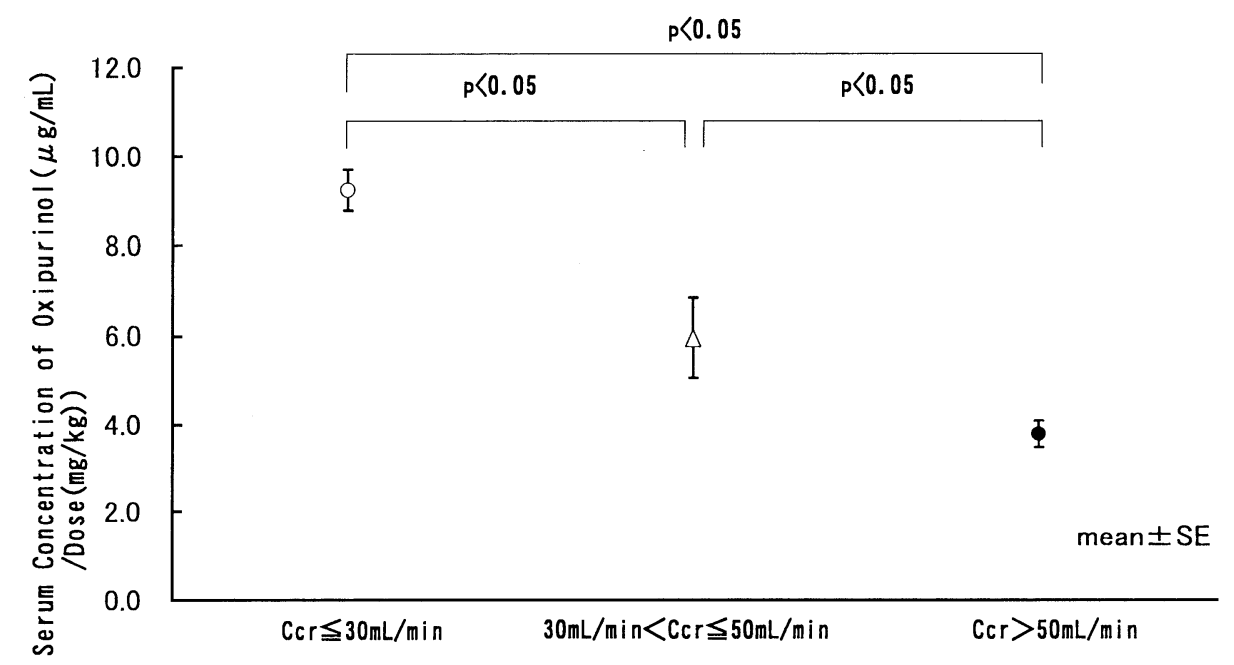

Fig. 4. Comparision of Serum Concentration of Oxipurinol $(\mu \mathrm{g} / \mathrm{mL}) /$ Dose $(\mathrm{mg} / \mathrm{kg})$ in Each Creatinine Clearance Group.

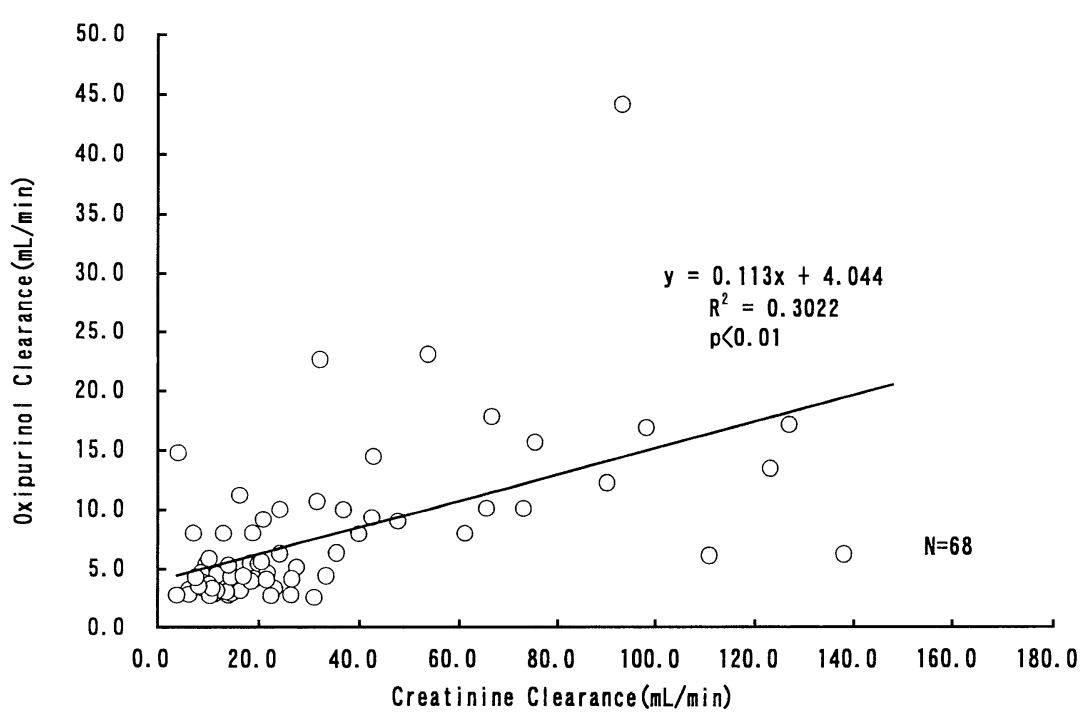

Fig. 5. Correlation between Creatinine Clearance and Oxipurinol Clearance.

存的に増加し, Fig. 2 から特に腎機能が低い患者ほど投 与量の増加に対する血清オキシプリノール濃度の上昇が 大きいことが認められた。すなわち，血清オキシプリ ノール濃度と副作用との関係は現在明らかでないが, 腎 機能低下患者では慎重に投与する必要があると考えられ た。

オキシプリノールの至適血中濃度について, Simmonds らは4.7〜 $15.2 \mu \mathrm{g} / \mathrm{mL}$ とすることが望ましいと報告して いる $2,3,7,8)$. 対象とした症例について, 腎機能別に至適 血中濃度域にある割合について調査した結果, A 群50例 中 19 例 $(38.0 \%)$, B 群17例 中11例 $(64.7 \%)$ C 群34例 中24例 $(70.6 \%)$ と, 腎機能が低下するほど至適血中濃
度域の症例が少なく, 特に $\mathrm{A}$ 群では半数以上の症例が 至適血中濃度を超えていた。

対象とした症例のうち血清オキシプリノール濃度が もっとも高かったのは $54.70 \mu \mathrm{g} / \mathrm{mL}$ であった．本症例 は, 他院から精査目的で転入した70歳男性患者で, 現病 歴として左腸骨動脈瘤, 不安定狭心症, 慢性腎不全, 既 往歴として痛風があり，このためアロプリノールを200 $\mathrm{mg} / \mathrm{day}$ で服用していた。投与期間は採血時点から少な くとも 5 カ月経過していた. 入院時の検査デー夕は, 血 清クレアチニン : $4.8 \mathrm{mg} / \mathrm{dL}, \mathrm{BUN}: 86 \mathrm{mg} / \mathrm{dL}$, 尿酸： $7.6 \mathrm{mg} / \mathrm{dL}$, 赤血球: 330 万 $/ \mu \mathrm{L}$, 白血球数: $8430 / \mu \mathrm{L}$, $\mathrm{AST} ： 18 \mathrm{U} / \mathrm{L}, \mathrm{ALT} ： 9 \mathrm{U} / \mathrm{L}$, クレアチニンクリアラン 


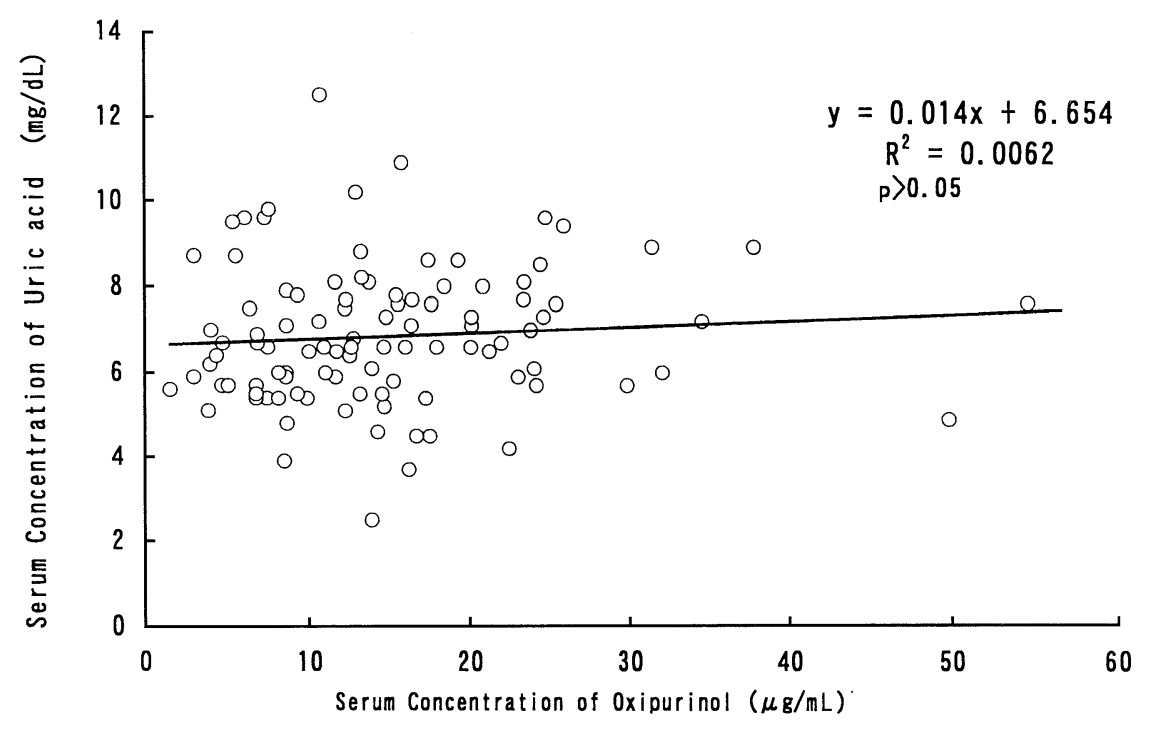

Fig. 6. Correlation between Serum Concentration of Oxipurinol $(\mu \mathrm{g} / \mathrm{mL})$ and Uric Acid $(\mathrm{mg} / \mathrm{dL})$.

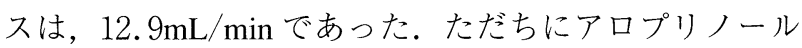
を 2 日間中止後 $100 \mathrm{mg} /$ day で再開し， 2 力月後の血清才 キシプリノール濃度は $20.5 \mu \mathrm{g} / \mathrm{mL}$ （血清クレアチニン： $5.1 \mathrm{mg} / \mathrm{dL}, \mathrm{BUN}: 77 \mathrm{mg} / \mathrm{dL}$ ，尿酸： $8.1 \mathrm{mg} / \mathrm{dL})$ であっ た. Hande らは，紅斑，剥脱性皮䖉炎などの皮膚障害が 血清クレアチニン $1.8 \sim 7.9 \mathrm{mg} / \mathrm{dL}$ の患者に，アロプリ

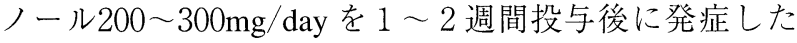
と報告している4)。また，汎血球減少，再生不良性貧血 などの血液障害が血清クレアチニン $1.9 \sim 6.9 \mathrm{mg} / \mathrm{dL}$ の 患者に，アロプリノール50〜200mg/day を 2 カ月〜 6 カ 月投与後に発症したとの報告もある ${ }^{9-13)}$. しかし，今回 対象とした至適血中濃度域を超える症例においてはオキ シプリノールの蓄積が原因と考えられる皮膚障害（発 疹, 紅斑, 剥脱性皮膚炎等) 肝機能障害, 汎血球減少な どの副作用の発現は認められなかった。このことは，副 作用の発現は血清オキシプリノール濃度だけが原因では ないとの池田らの報告と一致する ${ }^{14)}$.

一方，オキシプリノールは腎排泄型の代謝物であり， 腎機能低下患者において血清オキシプリノールの蓄積が 原因と考えられる重篤な副作用が多く報告されている。 このオキシプリノールの蓄積による副作用を防止するた め, Hande, 細谷らは腎機能別のアロプリノール投与指 針を提唱している。

Hande らは，腎機能正常症例に基づいた Ccr から血清 オキシプリノールを予測しアロプリノール投与量指針を 提唱している.

細谷らの投与指針は経験的に確立されたものと推定さ れる。
しかし，これらの指針にはかなりの違いがある。たと えば $\mathrm{A}$ 群 $(\mathrm{Ccr} \leqq 30 \mathrm{~mL} / \mathrm{min})$ の患者では，Hande，細谷 での投与量はそれぞれ $100 \mathrm{mg} /$ day, $50 \mathrm{mg} /$ day となり 2 倍の違いがある。そこで，オキシプリノールクリアラン スについて検討した。

オキシプリノールクリアランスは，アロプリノールが すべて吸収され，ただちにオキシプリノールに変換する と仮定して算出されたものであるが，Fig. 5 から正常な 腎機能の場合，オキシプリノールクリアランスは約 15 $\mathrm{mL} / \mathrm{min}$ と推定され, Elion ${ }^{15)} ら の$ 報告とほぼ一致した. 投与量が異なる原因がオキシプリノールクリアランス以 外にある可能性が示唆された。

Fig. 6 から，尿酸值と至適血清オキシプリノール濃度 には相関性がない。このため，尿酸值だけを指標にして アロプリノール投与量を設定すると，血清オキシプリ ノール濃度が上昇し，副作用が起こる可能性が高くなる ことが示唆された。

Fig. 2 の結果から，至適血清オキシプリノール濃度を $4.7 \sim 15.2 \mu \mathrm{g} / \mathrm{mL}$ とし，体重60kgの患者におけるアロ プリノールの至適投与量について検討を行ったＡ群 $(\mathrm{Ccr} \leqq 30 \mathrm{~mL} / \mathrm{min}) ， \mathrm{~B}$ 群 $(30 \mathrm{~mL} / \mathrm{min}<\mathrm{Ccr} \leqq 50 \mathrm{~mL} / \mathrm{min})$, $\mathrm{C}$ 群 $(\mathrm{Ccr}<50 \mathrm{~mL} / \mathrm{min})$ 各群の回帰直線をもとに，アロ プリノール投与量を A 群 $50 \mathrm{mg} /$ day, B 群 $100 \mathrm{mg} /$ day, C 群 $200 \mathrm{mg} /$ day とした場合の予測血清オキシプリノール濃 度を計算すると，それぞれ $7.4 \mu \mathrm{g} / \mathrm{mL}, 7.7 \mu \mathrm{g} / \mathrm{mL}, 11.7$ $\mu \mathrm{g} / \mathrm{mL}$ であり，すべて至適血中濃度域に入った。しか し， C 群 $(\mathrm{Ccr} \geqq 50 \mathrm{~mL} / \mathrm{min})$ の患者にアロプリノール300 $\mathrm{mg} / \mathrm{day}$ 投与した場合の予測血清オキシプリノール濃度 
は, $16.5 \mu \mathrm{g} / \mathrm{mL}$ と至適血中濃度を超える可能性が示唆 された。

以上のことから, Hande より細谷らの投与指針の方が 適していると考えられる。しかし C 群 $(\mathrm{Ccr}>50 \mathrm{~mL} / \mathrm{min})$ の患者において $300 \mathrm{mg} /$ day 投与した場合, 血清オキシプ リノール濃度が至適血中濃度域を超える可能性があるた めアロプリノール 1 日100～200mg の服用量で開始し， 治療効果が十分得られない場合, 尿酸值, 副作用等に注 意しながら，300mg まで増量するのが最適な投与方法 と考えられる。事実，対象とした101例のうち95例 (94.06\%) が1 日50 200mg の投与で，300mg 投与例 は 6 例 $(5.94 \%)$ と少なく全般的に適切な投与量であっ たと考えられる。

高尿酸血症は, 虚血性心疾患・脳血管障害の危険因子 と考えられており, 循環器疾患を併発している腎機能低 下患者では，尿酸排泄促進剤より尿酸生成阻害剤のアロ プリノールを長期間服用する場合が多い. 現在，オキシ プリノールの至適血中濃度および副作用の発生機序は十 分解明されていないが, 体内でのオキシプリノールの蓄 積が原因と考えられる副作用報告が多くあることから， 副作用を防止するため, 特に腎機能低下患者への投与に ついては慎重に行うべきであり，今後腎機能に基づいた より細かな投与指針の確立が望まれる。

\section{引用文献}

1）細谷龍男，市田公美，田部晃，酒井紀，高尿酸血 症の治療に関する研究, Allopurinol, Oxipurinolの 体内動態と薬効，リウマチ， 31，28-35(1991).

2) G.B. Elion, A. Kovensky, G.H. Hitchings, Metabolic studies of Allppurinol, an Inhibition of Xanthine oxidase, Biochem. Pharmacol., 15, 863-880(1966).

3) K.R. Hande, E. Reed, B. Chabner, Allopurinol kinetics, Clin. Pharmacol Ther., 23, 598-605(1978).

4) K.R. Hande, R.M. Noone, W.J. Stone, Severe Allopurinol toxicity. Description and guidelines for pre- vention in patients with renal insufficiency, Am. J. Med., 76, 47-56(1984).

5）細谷龍男，“腎機能と尿酸コントロール”ファー マインターナショナル, 東京, 1998, p.34.

6）宮崎亀, 松永義正, 橋本昌久, 高速液体クロマト グラフィーによるアロプリノール，オキシプリ ノールと関連プリン体, ピリミジン体の同時定量 法，医学のあゆみ，122，129-133(1982).

7) H.A. Simmonds, J.S. Cameron, G.S. Morris, P.M. Davies, Allopurinol in renal failure and the tumor lysis syndrome, Clinica. Chim. Acta., 160, 189-195 (1986).

8) G.P. Rodan, J.A. Robin, S.F. Tolchin, G.B. Elion, Allopurinol and gouty hyperuricemia, Efficacy of single daily dose, JAMA, 231, 1143-1147(1975).

9）田部晃，林知子，市田公美，細谷龍男，酒井紀, Allopurinolによると思われる骨髄抑制をきたした 慢性腎不全の1例，プリン・ピリミジン代謝， 16, 23-30(1992).

10）岡藤浩一郎, 篠原健次, 腎不全時に投与された $\mathrm{Al}-$ lopurinol が発症の原因と考えられた再生不良性貧 血の 1 例, 臨床血液, 31, 85-88(1990).

11) K. Matushita, K. Ikegami, H. Fukui, Aplastic anemia in a patient with end-stage renal disease caused by Allopurinol, Nippon Jinzo Gakkai Shi, 27, 13331337 (1985).

12）大野岩男, 石田裕一郎, 細谷龍男, 小林正之, 酒 井紀, Allopurinol 投与により再生不良性貧血を呈 した慢性腎不全の 1 例，リウマチ，30，281-286 (1990).

13) K. Shinohara, K. Okatuji, H. ayame, Aplastic anemia caused by Allopurinol in renal insufficiency, Am. J. Hematol., 35, 68(1990).

14）池田斉, 市田公美, 細谷龍男, 酒井紀, Allopurinol の副作用に関する研究，プリン・ピリミジン 代謝， 13，96-105(1990).

15) G.B. Elion, T.F. Yu, A.B. Gutman, G.H. Hitchings, Renal clearance of Oxipurinol, the chief metabolite of Allopurinol, Am. J. Med., 45, 69-77 (1968). 